Meta

Journal des traducteurs

Translators' Journal

\title{
Translated and Adapted - The Influence of Time on Translation
}

\section{Paula Rossi}

Volume 48, numéro 1-2, mai 2003

Traduction pour les enfants

Translation for children

URI : https://id.erudit.org/iderudit/006963ar

DOI : https://doi.org/10.7202/006963ar

Aller au sommaire du numéro

Éditeur(s)

Les Presses de l'Université de Montréal

ISSN

0026-0452 (imprimé)

1492-1421 (numérique)

Découvrir la revue

Citer cet article

Rossi, P. (2003). Translated and Adapted - The Influence of Time on Translation. Meta, 48(1-2), 142-153. https://doi.org/10.7202/006963ar

\section{Résumé de l'article}

Cet article décrit comment les contes de fées du célèbre écrivain du xix ${ }^{\mathrm{e}}$ siècle, Zachris Topelius, ont été traduits à différentes périodes du finnois à l'anglais. Les contes de fées véhiculent les idéaux personnels de Topelius en matière d'instruction - en l'occurrence, des notions bibliques et religieuses de même que morales et éducatives. Les auteurs de traductions récentes ont trouvé nécessaire de modifier les textes sources afin de les rendre plus accessibles aux enfants d'aujourd'hui. Dans le présent article, l'accent est mis sur les choix des traducteurs. 


\title{
Translated and Adapted - The Influence of Time on Translation
}

\author{
PAULA ROSSI \\ University of Oulu, Oulu, Finland \\ paula.rossi@oulu.fi
}

\begin{abstract}
RÉSUMÉ
Cet article décrit comment les contes de fées du célèbre écrivain du XIX $x^{e}$ siècle, Zachris Topelius, ont été traduits à différentes périodes du finnois à l'anglais. Les contes de fées véhiculent les idéaux personnels de Topelius en matière d'instruction - en l'occurrence, des notions bibliques et religieuses de même que morales et éducatives. Les auteurs de traductions récentes ont trouvé nécessaire de modifier les textes sources afin de les rendre plus accessibles aux enfants d'aujourd'hui. Dans le présent article, l'accent est mis sur les choix des traducteurs.
\end{abstract}

\begin{abstract}
In this paper I will examine how the fairytales written by Zachris Topelius, the famous 19th century Finnish storyteller, were translated into Finnish and into English at different times. The fairytales contain Topelius' personal ideals of upbringing, biblical and religious as well as moral and educational elements, for instance. The authors of the more recent translations have considered it necessary to modify the source texts so that they would be more accessible to today's children than the earlier Finnish translations. In my analysis, I focus on the translational choices made by the translators.
\end{abstract}

MOTS-CLÉS/KEYWORDS

Topelius, fairytales, translation for children, translational choices, source text

Introduction

Do translators use different strategies at different times in their work, and what sorts of changes can the translator make to the source text? In other words, is the translator faithful to the time and style of the original writer, or does the surrounding world and the time in which the translator lives affect the outcome of the translation? To answer these questions I have chosen to examine the Swedish fairytales written by Zachris Topelius in the 19th century, as they bring forth Topelius' own ideals of upbringing. Also, these fairytales have inspired a number of various translations. From the standpoint of later times, Tove Jansson, an internationally renowned author and illustrator of the Moomins fairytales of the latter half of the 20th century, pertinently expresses the attitudes towards Topelius' fairytales: she characterizes them as mixtures of Romanticism and primitivism (Furuland \& Lindberger \& Ørvig 1976: 369).

Zachris Topelius was born near the town of Uusikaarlepyy in 1818, after which he attended school in Oulu and Helsinki. He took the Master of Arts degree in Helsinki in 1840. (Suomen Kirjallisuus III 1964: 290, 292-293) Topelius' literary production is extensive and manifold: he wrote fairytales, poetry, stories, presentations, historical novels, aphorisms, travel journals, newspaper articles, speeches and schoolbooks (Seppälä 1998: 42). Undoubtedly, as a poet, historian, academic, journalist, 
and pedagogue, he is an important part of late 19th century Finnish cultural history. Even today Zachris Topelius is seen as a living part of the cultural history of the Finnish Swede, the Swedish and the Finnish. (Widén 1998: 29)

This paper is a part of my larger research, which aims to unearth how Topelius' fairytales have been translated into various languages in the course of time and how they have been modified in the new Swedish versions. Furthermore, my intention is to examine how the fairytales have been adapted to different times and cultures. (cf. Huhtala 1998: 2000)

In this paper, I have chosen as my material two fairytales written by Zachris Topelius to be compared with the different translations of the texts. The original fairytales in the material are taken from the collection Läsning för barn (Lukemisia lapsille; 1865-1896), which consists of eight volumes. The series includes fairytales, educational stories, poems, playful tasks, dialogues, and plays. (Seppälä 1998: 45) Topelius wrote in Swedish, the other of the two official languages of Finland besides Finnish. For this reason, his texts have been translated into Finnish in Finland. The first fairytale to be looked at is Adalminas pärla (AP 1893) and its two Finnish translations, Adalminan helmi ${ }^{1}$ (AH 1946), and a more recent Finnish translation with a similar title published in 1990 (AH 1990). The second fairytale to be investigated in this paper is entitled Rida ranka (RR 1883), which will be compared with two similarly entitled Finnish translations, Blankan ratsastaja² (BR 1947, BR 1990). The material also includes the English translation of the fairytale, entitled Riding Ranka (RR 1973) from 1973.

Adalminas pärla is a fairytale about a princess called Adalmina, who is the only child of the monarch. At her christening she receives a gift from two fairy godmothers. The first fairy gives her a pearl, which helps the princess to become prettier, richer and wiser day by day. If Adalmina loses her pearl, she will also lose all these three qualities, but will, in return, receive a good and humble heart from the other fairy godmother. Adalmina develops into a beautiful princess, who is very much aware of her beauty. One day she loses the pearl and forgets who she is. At the same time she receives the qualities endowed by the other fairy godmother. Adalmina finds a place to stay in the home of a poor old woman. Years go by before a prince finds the crown to which the pearl is attached. From all over the kingdom, young girls stream in to try on the crown, and so does Adalmina, who is the only one whom the crown fits. Adalmina gets back the gift given by the first fairy godmother and she also gets to keep the noble and humble heart. The underlying lesson of the fairytale is that it is more important to have a humble heart than earthly properties. Humbleness is, according to Laurent, too, the educational objective of this particular fairytale (1947: 228).

In the fairytale Rida ranka Topelius has employed elements from an old nursery song Rida, rida ranka, which is known in Swedish, Norwegian, Danish and German (Laurent 1947: 132; see also Furuland \& Lindberger \& Ørvig 1976: 239-242). Haakon, the Crown Prince of Sweden and Norway, is riding on his mother, Queen Blanca's, knee. At the same time the Queen sings him a song called Rida, rida ranka, in which she hopes that her son will eventually marry Margaret, the princess of Denmark, and thus extend the kingdom. The Queen's wish comes true: Margaret and Haakon meet and get married. Later Haakon sings the same song to his own son, and in this way the song persists from one century to another. 


\section{Topelius as a fairytale poet}

Children's literature was markedly didactic and educational in the Nordic countries before the 19th century. It passed on Christian doctrines with an attempt to embed a sense of morality and the right ways of life in the minds of children. Children's literature provided young audiences with information that was considered useful for their education. After the 19th century the objectives of children's literature became blurred and the didactic purposes were not portrayed as clearly as before. The ideas about children and childhood changed along with the social changes toward an industrial society. A more imaginative and entertaining grip in literature was taking over the moral and enlightening values, which had previously been the predominant topics in literature. (Møhl \& Schack 1981: 13)

Topelius shared the values of his time and was of the opinion that the children's upbringing had to be first and foremost Christian which is why religiosity is one of the basic elements in Topelius' fairytale poetry. The fairytales make frequent references to prayers, gratitude, respect and humility - in other words, they contain many elements from the Bible and religion. Another argument that Topelius included in his fairytale poetry was that the upbringing should be patriotic. Home and childhood memories represented the fatherland in the fairytales. Similarly, moral and educational ideas, such as humility, diligence, spirit of comradeship, love, truth and victory over self, were recurring themes in Topelius' fairytales. (Laurent 1947: 58, $195,223,328$ )

\section{About translation and translation shifts}

The writer of the source text and the translator do not share the same point of departure in the work. When the translator gets to work, the source text has already been written and stylized. The source text is the outcome of many different factors, which include the environment (country, time, culture, client, target group etc.), the writer (characteristics, experience, skills etc.), and the textual traits (language, genre, style, etc.). Likewise, the translation, too, will be affected by the above mentioned factors as well as by the translator's own surroundings and personal skills, knowledge and translation methods. (Huhtala 1995: 25-26) For this reason, during the translation process the source text will be altered in various ways, which can be called translation shifts. Translation shifts may be due to structural differences between languages, or the translator may change the text to make it easier to understand. As well, the translator may be tempted to make various changes because of the text type. (Huhtala 1995: passim) When working with a translation, the translator often adds new elements to the text or deletes some elements. Because of the additions, the translation may either receive new implications or the stories do not change in any considerable way, but the translation becomes more explicit in its message compared to the source text. Similarly, omissions may change the meaning of the source text. Then again, these omissions may be single elements whose significance can be deduced elsewhere from the text. (Ingo 1990: 293-294) These additions and omissions are made for various reasons: the translator has possibly tried to make the text more reader-friendly by clarifying the text, simplifying the linguistic structure, or alleviating the translation process with the change. etc. (Huhtala 1995: 153) 
The use of various translation shifts employed by the translators varies considerably depending on the period (Huhtala 1998: passim), as every epoch in history has had its own ideals. The translators may have conspicuously followed the source text and tried to maintain its form and content, while sometimes no distinction was made between the translation and one's own writing (see, e.g., Bassnett 1995: 57-95, Sorvali 1983: 13-14).

\section{Comparison}

As is common with Topelius' fairytales in general, Adalminas pärla is a fairytale that contains religious ingredients. At the beginning of the fairytale, Topelius points out that God is to be loved more than anything else. Topelius mentions the catechism and insists that children were not allowed to forget its lessons:

...ty Gud tycker icke om att man håller af någon med en afgudisk kärlek. Då glömmer man det som står i katekesen, att man skall älska Gud af allt sitt hjärta och af all sin själ. $(\text { AP } 1893)^{3}$

In the old Finnish translation this part has been preserved:

...sillä Jumala ei suvaitse, että ketään epäjumaloidaan. Silloin unohdetaan katkismuksen sanat, että tulee rakastaa Jumalaa kaikesta sydämestä ja kaikesta sielusta. (AH 1946) ${ }^{4}$

In a more recent translation (1990) God, though implied, is no longer mentioned by name. The Finnish translator does not mention the catechism either. The translator has probably considered it to have less value for children than in Topelius' days, and that children are not familiar with the catechism.

Onnessaan he tyystin unohtivat, että on vain yksi ainoa, jota tulee yli kaiken rakastaa ja kunnioittaa. (AH 1990) $)^{5}$

In a similar manner, the following example touches upon a religious element: for Topelius, beauty, wealth, and wisdom were not to be considered as sins provided that these talents were used in accordance with God's will:

...det är ingen synd att vara vacker och rik och klok, endast man förstår att bruka dessa gåfvor efter Guds vilja... (AP 1893) ${ }^{6}$

In the more recent Finnish translation this extract has been changed so that the talents ought to be used in the right way, but apparently God's will has been regarded as unnecessary information to be included:

...sillä ei ole synti olla kaunis ja rikas ja viisas, kunhan vain ymmärtää käyttää lahjojaan oikein. $\left(\right.$ AH 1990) ${ }^{7}$

The source text mentions the church. When the King and Queen realized that the princess was missing, everyone were ordered to dress in black, and there was an announcement of a reward in the church:

De läto kläda hela sitt rike i sorgdräkt och lyste i alla kyrkor, att den som kunde skaffa prinsessan Adalmina till rätta, han skulle få prinsessan till fru... (AP 1893) ${ }^{8}$

What is more, when the king learned that the princess' pearl had been found, he declared in the church that every 18 year-old was ordered to gather in the yard of the castle to try on Adalmina's crown: 
Därför lät han ånyo lysa i kyrkorna, att alla flickor som voro aderton år gamla, skulle församlas på hans gård och försöka kronan. (AP 1893) ${ }^{9}$

In the 1947 Finnish translation these passages have been preserved. In the more recent translation, however, the church is no longer included. The task of the church to spread information in society has changed over the decades, and the church does not reach people in the same way as it did before. In the more recent Finnish translation these announcements were merely referred to as matters to be made known all over the kingdom.

Topelius compares the humble Adalmina with good and pious people, who resemble angels with large white wings:

Och hvar Adalmina gick, där blef ånyo solsken omkring henne, men icke mera af hennes yttre förgängliga fägring, utan af den stilla förklaring, som skiner omkring de goda och fromma på jorden, hvilkas själ strålar af skönhet, såsom änglarnas anleten, när de med sina stora hvita vingar sänka sig ned till denna världens dalar. (AP 1893) ${ }^{10}$

In the earlier Finnish translation these elements have been retained without any major alterations. In the more recent translation the angels are mentioned, but the reference to their wings has been omitted:

Adalminaa ympäröi jälleen säteily, mutta enää se ei ollut kauniin ulkokuoren aiheuttamaa kylmänkalseaa loistoa, vaan heijastusta siitä sisäisestä valosta, joka hehkuu kuin lämmin liekki jokaisen hyvän olennon - ennen muuta hyvien enkeleitten sisimmässä ja jonka lämmöstä meistä jokainen voi päästä onnelliseksi. (AH 1990) ${ }^{11}$

The moral and educational ideas come forward also in the Adalminas pärla fairytale. Adalmina has a humble heart and she received many good gifts such as good conscience, calm contentment, rest, peace, goodness, and love. With the help of these she would get along in the world, whatever difficulties she was to face.

Mycket bättre var hon nu, än förut, ty med ett ödmjukt hjärta följa många kostliga gåfvor, såsom ett godt samvete och stilla förnöjsamhet, lugn och frid, godhet och kärlek, ehvart man än i världen hamnar. (AP 1893) ${ }^{12}$

In the earlier translation this piece has been preserved, while in the more recent translation the characteristics represented by a humble heart are not listed.

For Topelius, poverty represents an honorable reliance upon self (Syväoja 1998: 20). Poverty is emphasized also in his fairytales (cf. Huhtala 2000: 149-150) as the following extract suggests, whereas in the more recent translation this topic has been eliminated:

Se, den gode Guden vill att jag skall taga den fattiga till min hustru... (AP 1893) ${ }^{13}$

Luojan tahto on, että otan hänet puolisokseni... (AH 1990) ${ }^{14}$

Towards the end of the fairytale Topelius lays emphasis on how the poor and the ugly with a clear conscience are much happier than the rich and the beautiful with their pride.

...och huru den fattiga och fula är mycket lyckligare med sitt samvetes frid, än den rika och den sköna med allt sitt högmod. (AP 1893)

According to the source text, Adalmina shares a home with a poor old woman. In the new Finnish translation the old woman is gentle and old; the translator has not 
emphasized her poverty. When prince Sigismund finds Adalmina, he considers her köyhä ja ruma ${ }^{16}$. The more recent Finnish translation contains a milder choice of words as the girl is referred to with an expression vähäpätöisen näköinen tyttö ${ }^{17}$.

According to Laurent, in his fairytales Topelius employs formal patterns similar to those in folktales. As an example of these structures she mentions the way the fairytales begin. (Laurent 1947: 262) The fairytale Adalminas pärla, too, begins with the formally structured phrase olipa kerran ('once upon a time'), which is characteristic of fairytales (det var en gång):

Det var en gång en konung och en drottning, som hade en liten flicka... (AP 1893) ${ }^{18}$

The Finnish translations employ the lexical equivalent oli kerran ('once there was'). This kind of a beginning is also common today.

Adalminas pärla fairytale ends in a statement that captures the lesson of the entire fairytale: Adalmina's pearl is beautiful, but a humble heart is many times more beautiful.

Vacker, vacker är Adalminas pärla, men mycket vackrare är ett ödmjukt hjärta! (AP $1893)^{19}$

In the older Finnish translation the original idea of the source text has been preserved:

Kaunis, kaunis on Adalminan helmi, mutta paljon kauniimpi on nöyrä sydän! (AH $1946)^{20}$

In the above, the fairytale concludes in a statement that touches upon all the people. Then again, in the new translation this thought is confined to Adalmina and her heart:

Mutta ihaninta on, että Adalminalla on sydän, joka on helmeäkin jalompi! (AH 1990) ${ }^{21}$

Also the fairytale Rida ranka ends in a general statement about the mortality of the royal and the immortality of the songs:

Konungar, drottningar, prinsar och prinsessor dö, liksom andra; men vackra och glada visor dö icke: de rida ranka på sångens toner från slägte till slägte. (RR 1883) $)^{22}$

The older Finnish translation carefully follows the source text with the exception that the prince is not mentioned at all, whereas the English version lacks both the princes and the princesses.

Kuninkaat, kuningattaret, prinsessat kuolevat, niin kuin muutkin ihmiset; mutta kauniit ja iloiset laulut eivät kuole; ne ratsastavat sävelten siivillä ajasta aikaan. (BR $1947)^{23}$

Kings and queens die like everyone else, but the good, happy songs do not; they ride on from one generation to another. (RR 1973)

In his fairytales, Topelius frequently refers to characters and places by name which adds to the sense of reality in the fairytales. In this regard, Topelius' fairytales differ from the fairytales written by the Grimm brothers. (Laurent 1947: 327) The translator has various possibilities in "translating" the names of the characters. The translator can use the same name as in the source text, which is the method used most often, since the names usually do not bear any particular meaning (see Ingo 1990: 241). Secondly, the translator may adjust the name of the source text to better correspond 
to the pronunciation rules of the target language. The third possibility is to replace the name of the source text with a name from the target language. The fourth possibility is to translate the name. This is possible when it comes to the epithets of the monarchs, for instance. (Huhtala 1995: 96) In the fairytale Adalminas pärla, both Finnish translators have used the form "Adalmina" according to the source text. The fairy godmothers do not have any particular names in the source text. They are referred to with expressions such as punainen haltijatar ${ }^{24}$ (den röda féen) and sininen haltijatar ${ }^{25}$ (den blå féen) and they are written with small initial letters. In the older Finnish translation the words punainen ('red') and sininen ('blue') are translated, but the more recent translation introduces the reader to words such as Punetar ${ }^{26}$ and Sinetär, and the translator has written them with capital letters, thus transforming them into names.

The fairytale Rida ranka portrays real-life figures from history, such as Blanca, Haakan and Magnus, who have received new forms in the translations. The following table brings together some of the names that are presented in the fairytale:

\section{Names in different versions}

\begin{tabular}{|l|l|l|l|}
\hline RR 1883 & BR 1947 & BR 1990 & RR 1973 \\
\hline Blanca & Blanka & Blanka & Blanca \\
\hline Håkan & Hookan & Haakon & Haakan \\
\hline Magnus & Maunu & Maunu Eerikinpoika & Magnus \\
\hline Birger Jarl & Birger Jarl & - & - \\
\hline Margareta & Margareeta & Margareeta & Margaret \\
\hline Märta & Mertta & - & Marta \\
\hline Olof & Olavi & Olavi & Olof \\
\hline
\end{tabular}

As the table shows, the Finnish translators have used various equivalents for some of the names, as is the case with the name Håkan for instance: in the older translation it has been written in the way it is pronounced in Swedish. In the English version the name Birger Jarl is not mentioned. It is likely that the translator did not find it necessary to give the English readers any detailed account of the history of Finland:

Eller var det hans mening att rida bort till Finlands djupa skogar, der hans farfars farfar, den store Birger Jarl, hade fordom kämpat mot troll och hedningar? (RR 1883) ${ }^{27}$

Or did he want to ride away to the deep forests of Finland, where his father's greatgrandfather once fought trolls and heathens? (RR 1973)

This particular part related to the history of Finland has been left out completely from the new Finnish translation.

At the beginning of the fairytale, Topelius tells his readers that King Maunu Eerikinpoika ('Magnus Ericsson') ruled both Sweden and Finland:

Hans fader konung Magnus rådde öfver allt Sveriges rike och Finland... (RR 1883) ${ }^{28}$

At the time of writing, Norway, too, belonged to the kingdom of Sweden. In the more recent Finnish translation this information has been added to the beginning of the 
fairytale, as is the case in the English translation of the text. Readers of the new translations may not be familiar with this information, but it can also be assumed that it was not very widely known even in Topelius' days. During this time, as we know, Finland was annexed to Russia as an autonomous Grand Duchy. By their choices, the translators have made sure that the readers will receive accurate historical information.

His father, King Magnus, ruled over the whole of the kingdom of Sweden, Finland, and Norway... (RR 1973)

Despite the fact that numerals may be considered as an easy material to translate, I have indicated in my previous translation researches that numerals are very likely to bring about recurring unforced errors in the translations (Huhtala 1995: 85). The material investigated also in this paper contains either non-deliberate or deliberate translation shifts. In the fairytale Rida ranka the prince is eight years old according to the source text. In the English version, he has been changed into a five-year-old. Then again, in the more recent Finnish translation the boy's age is not mentioned. When the prince and princess Margaret met for the first time, she was 11 years old. In the English text the princess is one year older, in other words 12 years old. These changes may be regarded as unnecessary. On the one hand, they do not alter the actual story of the fairytale, but on the other hand it is difficult to see why the translator would end up using numbers that are different from the source text. In some instances, however, these alterations may be explained by the translator's attempt to conform to the rhythm of the text.

Laurent (1947: 133) points out that in folktales, age 15 is a crucial turning point in a character's lifespan. Adalmina loses her pearl at the age of 15 , and this number has remained the same in the Finnish translations.

In the Rida ranka fairytale it is told how the fairy godmothers brought Queen Margaret a little prince. This description has been preserved in the old Finnish translation, but the more recent Finnish translation as well as the English version have chosen not to adhere to the magical description; instead, the queen had the child without the assistance of the fairies. Nowadays children have knowledge that erodes their belief in fairies and mythical features, which may had an effect on the translator's choices:

...sai kuningatar Margareeta pienen kruununperillisen, prinssi Olavin. (BR/1990) ${ }^{29}$

...Queen Margaret had a little prince whom they called Olof. (RR 1973)

As one of the tasks of the fairytales is to teach children and provide them with new information, they often contained explanations, as can be seen at the beginning of the Adalminas pärla fairytale:

...och efter hon var en konungadotter, kallades hon prinsessa. (AP 1893) $)^{30}$

This explanation has been preserved in the oldest translation:

...ja koska hän oli kuninkaan tytär, niin häntä sanottiin prinsessaksi. (AH 1946) ${ }^{31}$

However, in the 1990s' Finnish translation this kind of explanation has been edited out. Explanations often also create needless repetitions in the source text, which is why the translators have excluded them as unnecessary. 
Because of the time gap between the original fairytale written by Topelius and its two translations, it is self-evident that some words would be modernized. One example of an interesting linguistic shift, which, on the basis of this material, does not seem to derive from differences in time, is the changes that have occurred in the way verbs are used in reporting clauses.

In the original Adalminas pärla fairytale the verb säga, 'sanoa, say,' receives various predicate equivalents in both Finnish translations. The 1990 Finnish translation features the following equivalents to the Swedish verb säga: huudahtaa ('exclaim'), ilmoittaa ('report'), jatkaa ('continue'), kuiskia ('whisper'), päättää ('conclude'), vastata ('reply') and virkkaa ('utter'). Likewise, the more recent Finnish translation of the Rida ranka fairytale contains various equivalents for the verb säga ('say'): ihastella ('wonder'), naurahtaa ('to give a laugh'), todeta ('remark'), and väistää ('evade'). Typical of the Finnish translation is that it is more elaborate in expressions related to speaking, as the following examples imply: sanoi suopeasti ${ }^{32}$ (sade ${ }^{33}$ ), räjähtää nauramaan ${ }^{34}$ (skrattade ${ }^{35}$ ), sanoa heläytti ${ }^{36}$ (sade), sanoi nauraen ${ }^{37}$ (sade). The Finnish translator has also left some reporting clauses untranslated. These omissions have not affected the clarity of the text, as the speaker of the fairytale can inferred from the textual context.

\section{Conclusion}

The more recent Finnish translations (both translations were done by the same translator) have modified the source text to a greater extent than the older Finnish translations. The publishing dates between the source texts and the new Finnish translations are so far apart that the author of the new Finnish translations has found it necessary to adapt the texts to the present time and make the new translations more accessible to children than the earlier translations. The reasons for this are many: among other things, children's knowledge has become much wider over the years, and religion no longer plays as dominant a role as before. Furthermore, both the social conditions and the moral and educational ideals have changed.

Translating makes a number of demands on the translators. They have to know when a change in the text is in order and how to carry out the changes. To what extent, then, can the translator modify the source text? Can we still talk about texts written by Topelius, if the translator has, for instance, left out a part of the religious elements of the fairytale, which for Topelius represented an important ideal in the upbringing of children? It is obvious that the translator has to change the text to make readers understand what it is about and to make them learn new things (as in the case of additional historical information). Furthermore, it is understandable that the translator's aim is to improve the text by correcting the "blemishes" made by the writer of the source text. On the other hand, it is also justified to ask whether it is right to change Topelius' style of writing by omitting repetitions, for instance. In her preface to the book Topeliuksen aarteet (1990), Irja Lappalainen, the translator of the new Finnish translations, states that the choices she has made in the translations could not have been possible a couple of decades earlier. She admits having condensed the texts and justifies her method by claiming that Topelius had been forced to prolong his source texts to make them sufficiently long for a journal (a part of the fairytales have been previously published as newspaper articles). She has omitted 
monotonously repeated scenes and sententious closing lines that she thought might have appeared comic to the readers.

The shifts that I have described here are not rare occurrences in translated literature. Consider, for instance, the French version of Astrid Lindgren's Peppi Pitkätossu, "Pippi Longstocking," in which Pippi has been changed into a good girl (Nu är fransmännen redo för den riktiga Pippi, Hbl 20.6.1993), or H.C. Andersen's Pieni tulitikkutyttö, "The Little Match Girl," which ends happily in the American version (Klingberg 1977: 186) (see Oittinen 1997). The Adalminas pärla fairytale has been rewritten in Swedish. The new version was published in 1984. It is interesting to note that some of the religious as well as the moral and educational elements have been edited out from this version, too.

Even if the fairytales written by Topelius may appear as comic in their original fabric, they nevertheless have their solid place and task in literature. Although Tove Jansson described them as mixtures of Romanticism and naivism, she confessed that they were her favourite readings in a day when everything had gone wrong (Furuland \& Lindberger \& Ørvig 1976: 369).

\section{NOTES}

1. 'Adalmina's pearl'

2. 'the rider of Blanca'

3. '.. for God does not tolerate the worship of any false gods. Then the words of the catechismus that God is to be loved from all heart and soul would be forgotten.'

4. '.. for God does not tolerate the worship of any false gods. Then the words of the catechismus that God is to be loved from all heart and soul would be forgotten.'

5. 'In their bliss they completely forgot that there is only one to be loved and honored above others.'

6. '... for it is not a sin to be beautiful, wealthy, and wise as long as these talents are used in accordance with God's will.'

7. ' '...for it is not a sin to be beautiful, wealthy, and wise as long as these talents are used right.'

8. 'They gave an order to the entire kingdom to dress in mourning and made an announcement in every church that he who finds princess Adalmina and takes her back, could marry her...'

9. 'Therefore, a new announcement was given in the church that ordered every girl of eighteen years of age to gather in his yard and try on the crown.'

10. 'And wherever Adalmina went, she was still surrounded by a radiating light, but that was no longer an unfriendly bleak shine educed by her outward beauty, but a silent glorification that shines around the good people on earth whose souls radiate with beauty, just like the faces of angels when they descend to earth, to the valleys of this world with their big white wings.'

11. 'Again, Adalmina was surrounded by a radiating light, but that was no longer an unfriendly bleak shine educed by her outward beauty, but a reflection of the inner light that glows like a flame inside every good creature - above all inside good angels - and that each and every one of us can attain happiness through its warmth.'

12. 'She was much better now with a humble heart, along with which many valuable gifts followed, such as good conscience amd calm contentment, rest and peace, goodness and love, which would help her to get along in the world.'

13. 'God's will is that I will marry this poor woman...'

14. 'God's will is that I will marry her...'

15. '.. and how the poor and the ugly who have peace of conscience are much happier than the rich and the beautiful who have their pride.'

16. 'poor and ugly'

17. 'a girl with unnoticeable looks'

18. 'Once upon a time there was a King and Queen who had a little girl...'

19. 'Beautiful, so beautiful is Adalmina's pearl, but far more beautiful is a humble heart!'

20. 'Beautiful, so beautiful is Adalmina's pearl, but far more beautiful is a humble heart!'

21. 'But the most wonderful thing of all, Adalmina has a heart that is far nobler than the pearl itself!' 
22. 'Kings, queens, princes, and princesses die like everyone else; but the beautiful and happy songs won't die; they ride on the wings of music from one time to another.'

23. 'Kings, queens, princesses die like everyone else; but the beautiful and happy songs won't die; they ride on the wings of music from one time to another.'

24. 'the red fairy godmother'

25. 'the blue fairy godmother'

26. The Finnish suffixes - ar and -är, which are added to the adjectives to form the names, as in the formation of Punetar from punainen ('red') and Sinetär from sininen ('blue'), refer to females as the corresponding suffix in English would be '-ess' as in 'actress' for instance.

27. 'Or did he want to ride away to the deep forests of Finland, where his father's great-grandfather, the great Birger Jarl, once fought trolls and heathens?'

28. 'His father, King Magnus, ruled over the whole of the kingdom of Sweden and Finland...'

29. ' '..QQueen Margaret had a little heir to the crown, prince Olof.'

30. ' '... and because she was the king's daughter, she was called princess.'

31. '... and because she was the king's daughter, she was called princess.'

32. 'said kindly'

33. 'said'

34. 'burst into laughter'

35. 'laughed'

36. 'said cheerfully'

37. 'said laughing'

\section{REFERENCES}

Primary sources

Adalminas pärla:

Topelius, Z. (1893): Adalminas pärla. In: Läsning för barn. Andra boken. Visor och sagor. Femte upplagan. Stockholm: Albert Bonniers förlag. 68-76.

Topelius, Z. (1946): Adalminan helmi. In: Lukemisia lapsille. Suomentajat V. Tarkiainen \& V. Juva \& I. Jäämaa. III nide. Seitsemäs täydellinen painos. Porvoo - Helsinki: Werner Söderström Osakeyhtiö. 73-84.

Topelius, Z. (1990): Adalminan helmi. In: Topeliuksen Satuaarteet. Suomentanut I. Lappalainen. Helsinki: Otava ja Suuri Suomalainen Kirjakerho Oy. 149-159.

Rida ranka:

Topelius, Z. (1883): Rida ranka. In: Läsning för barn. Fjerde boken. Lekar, visor och sagor. Tredje upplagan. Stockholm: Albert Bonniers förlag. 181-191.

Topelius, Z. (1947): Blankan ratsastaja. In: Lukemisia lapsille. Suomentajat V. Tarkiainen \& V. Juva \& I. Jäämaa. V nide. Kuudes täydellinen painos. Porvoo - Helsinki: Werner Söderström Osakeyhtiö. 194-205.

Topelius, Z. (1973): Riding Ranka. In: The Sea King's Gift and other tales from Finland. Retold by I. Kaplan. Great Britain: Frederick Muller Limited. 69-82.

Topelius, Z. (1990): Blankan ratsastaja. In: Topeliuksen Satuaarteet. Suomentanut I. Lappalainen. Helsinki: Otava ja Suuri Suomalainen Kirjakerho Oy. 277-287.

\section{Secondary sources}

Bassnett, S. (1995): Teoksesta toiseen. Johdatus kirjallisuuden kääntämiseen. Toimittanut ja suomennostyön ohjannut R. Oittinen. Tampere: Vastapaino.

Furuland, L. \& Lindberger, Ö. \& ØRVIG, M. (1976): Barnlitteratur i Sverige. Läsning för barn och barnboksprogram. ALMAserien 22. Stockholm: Wahlström \& Widstrand.

Huhtala, P. (1995): Från teori till praktik. Analys av översättningar från finska till svenska. Acta Universitatis Ouluensis. Humaniora. B 20. Uleåborgs universitet. 
Huhtala, P. (1998): Topeliuksen Pikku Matin eri versioista. In: Matkalla kielestä kieleen. Juhlakirja Rune Ingon 60-vuotispäiväksi. Toimittanut A. Niemikorpi. Acta Wasaensia. No 63. Kielitiede 13. Universitas Wasaensis.

Huhtala, P. (2000): Jämförelser mellan olika översättningar av Topelius saga Pikku Matti. In: Översättning och tolkning. Rapport från ASLA:s höstsymposium Stockholm 5-6 november. Utgiven av B. Englund Dimitrova. ASLA:s skriftserie 12. Uppsala: Association suédoise de linguistique appliquée. 145-153.

INGO, R. (1990): Lähtökielestä kohdekieleen. Johdatusta käännöstieteeseen. Porvoo - Helsinki Juva: Werner Söderström Osakeyhtiö.

Klingberg, G. (1977): Att översätta barn- och ungdomsböcker. Empiriska studier och rekommendationer. Lärarhögskolan i Mölndal.

Laurent, K. (1947): Topelius saturunoilijana. Porvoo - Helsinki: Werner Söderström Osakeyhtiö. Мøнц, B. and Sснаск, M. (1981): När barn läser. Litteraturupplevelse och fantasi. Gidlunds.

$\mathrm{Nu}$ är fransmännen redo för den riktiga Pippi (1993). Hufvudstadsbladet. 20.6.1993.

Oittinen, R. (1997): Liisa, Liisa ja Alice. Matkakirja. Tampere: Tampere University Press.

SEPPÄLÄ, A. (1998): Satumainen Zachris Topelius. Helsingin Sanomat. Kuukausiliite. Tammikuu 1998. 40-46.

SoRvali, I. (1983): Översättandets teori och praktik. Helsinki: Oy Gaudeamus Ab.

Suomen kirjallisuus III (1964). Toim. L. Viljanen. Helsinki: Suomalaisen kirjallisuuden seura ja Kustannusosakeyhtiö Otava.

SyväOJA, H. (1998): Topelius ennusti Suomen itsenäisyyttä. Opettaja 4/1998. 18-20.

WIDÉN, G. (1998): Topelius trotsar tiden. Hufvudstadsbladet. 11.1.1998. 29. 